\title{
The Reappropriation of Poverty and the Art of "Making Do" in Contemporary Argentine Cultural Productions
}

\author{
Víctor Goldgel-Carballo
}

\begin{abstract}
Through an analysis of two post-crisis films (Estrellas, Federico León and Marcos Martínez, 2007; El nexo, Sebastián Antico, 2005) shot in the largest slum in Buenos Aires, Argentina, this essay sketches the terms for conceptualizing a cultural dimension of the Global South marked by the aesthetic reappropriation of poverty. Working against what has been called Latin America's persistent "melodrama of poverty," and avoiding the type of cinematic representation that depicts the slum in terms of violence and uncertainty, the directors of these films highlight the fact that the reappropriation of poverty is often at the base of alternative forms of social and artistic agency. While the ability to work under conditions of material lack has long been an important dimension of Argentine artistic production, their films flaunt deprivation in order to transform precarity into an ideological and aesthetic weapon, re-staging social inequality in a spectacular fashion and advancing inventive modes of action. In this way, they argue that "making do" can also become the basis for an alternative creative paradigm. In their exploration of this paradigm, which allows slum inhabitants to build a house in two minutes and create a spaceship out of junk, both films pose far-reaching questions: who has a right to perform? What roles are available for the people of the slum? And, what are the conditions for having artistic and social agency in economically deprived areas?
\end{abstract}


"This is the first time that the state has such an active presence in a place like the Barracas slum, the most important in Buenos Aires."

(Cristina Fernández de Kirchner, current President of Argentina, announcing the 20I3 Relocation of the National Secretariat of Culture to the biggest slum in Buenos Aires) ${ }^{\mathrm{I}}$

Scholars engaged in the study of the Global South are familiar with the romanticization of poverty which accompanies the construction of "the postcolonial exotic" (Huggan vii, emphasis in the original). From the perspective of many first-world readers or spectators, the very suffering of the South seems to guarantee the value and the authenticity of its cultural products, as if poverty, pain, and vulnerability found their silver lining in an ostensibly closer proximity to a human "truth." As Julia Straub points out, engagement with texts marked by trauma stemming from the postcolonial world may serve to "compensate for the readers' perceived lack in their own lives, lives which appear to be deprived of first-hand experiences" in such a way that "[d]eprivation, stigmatization and marginalization come to be seen as means of empowerment" (17). But while Straub's economically privileged readers find value in precarity, which enables them to suffer vicariously and thus achieve some kind of Aristotelian catharsis, southern cultural agents are often pushed to put their precarity to work for their own benefit. As this essay argues, this reappropriation of poverty can be thought of as the cornerstone of a creative paradigm thatamong other things, as I will show-allows the inhabitants of Buenos Aires's biggest slum to assemble a spaceship out of junk and to build a house in two minutes and twenty seconds.

In a world that desperately needs effective paradigms for imagining poverty's eradication, the very act of describing it as a cornerstone might strike one as questionable. In the contemporary cultural production of a city like Buenos Aires, however, a critical acknowledgement of poor conditions is often at the base of agency; far from being a conformist rehashing of lack as plenitude, this reappropriation is often characterized by a satirical and defiantly carnivalesque drive that re-stages social inequality in a spectacular fashion and advances inventive modes of action. In stark contrast to public discourse in the US, where poverty often evokes shame, poverty in Buenos Aires is not conceived merely as an impediment; instead, it demarcates a site for distinctly creative forms of enunciation. In this context, material lack certainly does not disappear; on the contrary, by flaunting their material deprivation, subjects resignify it as a gateway to alternative forms of praxis and in this way transform the need to make do into the possibility of doing things differently. In this sense, a cultural Global South could be defined as one in which a material lack (vis-à-vis a real or imagined Northern plenitude) leads subjects to temporarily suspend their 
expectations for "proper" resources (e.g. wages, legally sanctioned spaces, the most adequate tools and materials, etc.) and to develop the kind of tactics and practices that are usually associated with the Lévi-Straussian figure of the bricoleur (17; see also Certeau 29). ${ }^{2}$

Resourcefulness, the ability to improvise, and the know-how required to work with odds and ends are products of poverty and can be therefore found in a wide variety of contexts and approached through different analytical models - in terms of the shrewdness with which people respond to the inefficacy of the state (García Villegas 12), for example, or along the lines of subaltern resistance (James Scott's "weapons of the weak"; Josefina Ludmer's similarly termed "tretas del débil" or "tricks of the weak"). In fact, the recurrence of terms that highlight the centrality of the art of "making do" across different nations-including the informal economic practices referred to in Cuba as the "invento" ("invention"), the more widely Spanish American "viveza criolla" ("creole cunning"), the Hindi "jugaad" (the ability to develop "quick-and-dirty" solutions [Jauregui 77]), and the imaginary article of the Congolese constitution, "Débrouillez-vous," which exhorts citizens to sort things out by themselves (Wild-Wood 367) — suggest potential for a global comparison. In this essay, however, I am specifically interested in cultural practices marked by a loud and ostensive reappropriation of poverty, one that, in the words of the Argentine theater director Ricardo Bartís, allows cultural workers "to transform the precarity of our means into an ideological and aesthetic force" (qtd. in Dubatti 118). In the Argentine case, as I point out in the last section of this essay, a strong history of political mobilization has contributed to making this reappropriation of poverty particularly resounding; in that sense, it should be distinguished from the "quiet encroachment of the ordinary" or the discreet and individual tactics of daily resistance more characteristic of areas governed by authoritarian regimes (Bayat 68).

I consider the creative paradigm that is fostered by the reappropriation of poverty in light of three different cases, which I approach as concentric circles: a low-budget science fiction film; a documentary that depicts its production; and the Buenos Aires scene of independent film, theater, and literary production in which the directors of both works have been immersed. These cases are marked by an effort to transform one's own poverty into something empowering and, in that sense, to strengthen the social agency of certain sectors of the Argentine population that can otherwise be described as marginalized and to foster a symbolic alliance between these sectors and middle-class or uppermiddle-class artists working with limited institutional and financial support. By re-staging social inequality in a spectacular fashion and positing precarity as an ideological and aesthetic weapon, these examples show that "making do" is not just a necessity but can also become the basis for an alternative creative paradigm. 


\section{EL NEXO}

The science fiction film El nexo (The Nexus, Sebastián Antico, 2005) is a prime example of an aesthetic exploration based on a reappropriation of poverty. Made on the cheap, with the cunning of the bricoleur and the materials available in the slum, it confronts spectators with aliens who invade Earth dressed in white plastic bags, troops of slum dwellers who resist the invasion armed with rotten water, and a spaceship that looks a lot like a classic Citroën $2 \mathrm{CV}$. In that sense, as Paola Cortés Rocca has argued, the film showcases and makes available for a wider public the particular know-how that develops in the context of an economic crisis ("La villa"). ${ }^{3}$ The film highlights a longstanding effort on the part of Argentine artists to create from within poverty-one that, for example, led the theater company De La Guarda to name its first production Periodo Villa-Villa, in reference to the 'villa' or slum-like methods they used to make it possible (Ruétalo 176).

For the most part, El nexo is a film about Villa 21-24 (Slum 21-24), where it was shot, and about its people. Located in the south side of Buenos Aires and home to 45,000 inhabitants, this is one of the most populated informal urban settlements in Argentina. At the time of the shooting, it was also home to the theater group organized by Julio Arrieta, the slum's most famous cultural agent. For the purposes of this film, Arrieta was the nexus, the leader who made connections possible - both between aliens and humans, in the film's diegesis, and between the slum and the rest of the city, in the making of El nexo and many other projects. A former Peronist puntero (ward boss), Arrieta later used his organizational skills to provide extras for TV and film productions. ${ }^{4} \mathrm{He}$ was also a writer, and El nexo was in fact based on one of his short stories. Up until his death in 2011, Arrieta insistently posed a question that illuminates the main force behind El nexo: Why don't aliens ever land in the slums?

To a certain extent, this question served as the project's guiding impetus: in contrast to other Argentine science fiction films like Moebius (Gustavo Mosquera, 1996), whose plots help to hide the lack of funds with which they are made, El nexo shows how this usually expensive and technologically-driven genre gives way to something quite different when marked by deprivation. As in B-movies, the lack of funds to create "proper" alien attire, weapons, and intergalactic vehicles did not lead Antico and the rest of the crew to avoid those topics; on the contrary, it served to highlight the unlikely development of such a story in the context of the slum. ${ }^{5}$ In an interview, Arrieta referred to the short story that would be the basis of El nexo as follows:

The whole planet is under the control of the aliens, until they get to Slum 21 in Barracas. By accident, one of the characters of the slum discovers the cure for these aliens, who were not harmed by any missile or atomic bomb.... He discovers that the only thing that harms them is the rotten 
water of the ditch of the slum [the mix of waste water and rain that forms due to the lack of sewage systems], and he attacks them with this water. He organizes the people of the slum and the people of other poor parts of the world, like Harlem in the U.S. and Liverpool in England, and all the poor neighborhoods of the planet adopt the method of Slum 21 in Barracas, they attack the aliens with the rotten water of their slums, and the world is free; covered by shit, but free. (qtd. in Graham-Yooll)

The aliens, in other words, are only defeated thanks to the slum. At least momentarily, the reappropriation of poverty turns the most vulnerable people into the most powerful, granting those subjects who have been marginalized a fundamental role: in the language of both commercial movies and war, they become heroes. But they are heroes of the abject: their main weapons are their degraded material conditions, of which the rotten water is just a synecdoche. If the slum can be thought of as the social residue globally produced by the failure of political and economic models, its wastewater must be understood as doubly abject: it has been refused, both from a social and a physical point of view.

Arrieta delineates the possibility of a planetary alliance between the poorest communities of the world, advancing a global frame mediated by a Northcentered mass culture: hence his interest, specifically, in Harlem and Liverpool. The film, however, also develops a highly local, nationalistic discourse made visible not only through the ubiquitous Argentine flags but also through a number of implicit references to national history. One of the shots depicting the attack on the aliens, for example, shows people throwing liquid from a roof-an action reminiscent of the way in which Argentines resisted the English invasions of Buenos Aires in 1806 and 1807 (Montaldo, "El mundo" 7). (My own astonishment as an elementary school student in Buenos Aires upon learning that the women of the city had participated in the war by throwing boiling oil on the English soldiers from the roofs of their homes might be one of the forces behind my interest in paradigms of "making do.") In the film, as during the invasions, the weapons of the subaltern end up being more powerful than those of technologically advanced armies. ${ }^{6}$ In comparison to the patriotic narratives that it evokes, however, El nexo is explicit about the fact that the nation is internally divided, underscoring that the invaders are defeated by slum-dwellers-i.e., by the nation's constitutive outside. ${ }^{7}$ The victory of Slum 21-24 over the aliens shows not only that planet Earth is safe again (albeit covered in shit) but also, and more emphatically, that a fight against a common enemy does not necessarily have to obscure internal forms of subalternity. 


\section{ESTRELLAS}

While it contains elements of fiction, Estrellas (Stars, Federico León and Marcos Martínez, 2007) began as a documentary about the process of filming El nexo. In keeping with the improvisational and fluid mode that characterizes independent theater and filmmaking in Buenos Aires, the directors worked in constant dialogue with Julio Arrieta, his neighbors, and the slum itself, thus creating a piece that is in great part a reflection on its own process of production. As León puts it in an interview: "The film was based on our own collaboration, as well as on the suggestions of the slum, Julio, his family, on spending fifteen hours a day there for two years; it found its form as we were doing it. There was no previous screenplay and we didn't know where we wanted to go with it" (qtd. in Halfon). As I show in the next section, this type of creative process in which the artwork emerges slowly and without a clear plan is far from exceptional in contemporary Buenos Aires.

As in the case of El nexo, Estrellas aims at avoiding the type of aesthetic representation that depicts the slum in terms of violence and uncertainty, as well as what the Mexican critic Carlos Monsiváis has termed Latin America's persistent "melodrama of poverty" (15). For example, while contemporary conventions assume that precarity requires a volatile and fragmentary visual language marked by the use of a hand-held camera, León and Martínez slow down the tempo and carefully set up long takes which may last several minutes. Dissuading viewers from the idea that the film depicts the unadulterated reality of the slum and eschewing the solemnity that often characterizes aesthetic encounters with poverty, they develop a humorous gaze that constantly shows its complicity with Arrieta's own ironic stance. The use of fiction throughout the "documentary" may be understood as a form of commitment to this gaze, one that refuses any clear-cut separations between the real and the imagined as well as between tragedy and farce. Rather than "melodrama," in fact, the film often looks like vaudeville: its characters and directors do not hesitate to entertain us by making fun of themselves-especially when "themselves" refers to the stereotypes with which the Argentine spectator is familiar.

Estrellas also revolves around the figure of Arrieta and the provocative questions he raises. In particular, the film explores the following: Why hire actors to play the roles of shantytown dwellers, when you can hire the shantytown dwellers themselves? While it was already present at the heart of El nexo, the key science fiction trope of the alien encounter is in this way further mined in Estrellas for its critical potential and links to contemporary labor economies; by openly acknowledging the fact that playing the "alien" (the addict, the prostitute, etc.) is the only job the people of the slum can get paid for, Arrieta simultaneously accepts marginality as a given and declares the need to put it to work for the benefit of Slum 21-24. If TV and film producers need images of 
"negros" ("blacks"), he states, then they should hire people from the slum instead of middle-class actors. (In Argentina, the word "negro" refers more to class than to skin color or phenotype, although darker skin is often read as a sign of lower-class status [Adamovsky 354]). As Arrieta points out, he and his neighbors "bear a face" (they are "portadores de cara"); he thus refers to the ways in which large groups of the population are segregated and criminalized based on racial and class profiling that includes their skin color, gestures, and physiognomy. But he also explores the possibility that, as actors, shantytown dwellers could reappropriate this status for monetary gain.

In one of its many excursions into fiction, Estrellas explores this problem by having Arrieta create a website that sells the type of roles available for the people of the slum (thief and policeman, for example, both played by the same actor) along with stereotypical locations (a house for kidnapping, an alley for fights, a dirt road for chase scene, etc.). But while acknowledging this reality, Arrieta also emphasizes his desire to change it, both through his explicit demand that Martians land in the slum and by the shooting of El nexo. In turn, however, this desire is also articulated through tropes that depend on the assertive display of poverty, which means that even utopian hopes are presented as impoverished. The fictional website affiliated with the project, for example, includes a section with "atypical roles"- such as nouveau-riche, foreign tourist, and hippie-constructed through humor and hyperbole. Another scene takes this slightly farcical utopian drive even further: the would-be actors of the slum are brought into a professional photography studio and portrayed as models or stars. The presence of cheaply-made tattoos, unstyled hair, and smiles with missing teeth mark the fundamental tension the film seeks out, epitomized by the picture of a shirtless, unshaved, wrinkly Arrieta gazing into the camera lens, an image that served as the movie poster and is on the cover of the DVD. In the same way that "normal" women who sometimes work as models in advertisement campaigns express first and foremost the fact that they are not professional models (they are not extremely tall or unusually thin, for example), Arrieta and his fellow slum-dwellers are photographed and framed as stars precisely because they do not look like them at all.

Exploring how Emmanuel Levinas's concept of the "face" might help us understand the ethical demands of those who lead precarious lives, Judith Butler has pointed out that the photographs of "others" often fail to represent their humanity, their suffering. For Levinas, she points out, "there is a 'face' which no face can fully exhaust, the face understood as human suffering, as the cry of human suffering, which can take no direct representation ... For representation to convey the human, then, representation must not only fail, but it must show its failure" (Precarious Life 144). In the case of Estrellas, the exhibition of this failure is taken to carnivalesque extremes, made possible by the reappropriation of poverty. And precisely because it highlights this failure, I would 
argue, the carnivalesque stance allows for a more accomplished representation of the "face." On the one hand, the slum-dwellers offer to play themselves (thief, drug addict, etc.), thus paradoxically capitalizing on their social exclusion and gaining visibility by engaging with stereotypes. In this way, as Gabriel Giorgi has argued, the film "dramatizes the insuperable contradiction of neoliberal 'inclusion' through individualization and privatization" (78). The images they sell of themselves express in the most absolute terms the shortcomings of a society that has confined them to its constitutive outside and is eager to pay to see them within that space. On the other hand, Arrieta and his fellow slum-dwellers aim at playing the role of conventional "stars." The ostensive difficulty of having someone with missing teeth occupying this position, however, foregrounds their true "faces" - the pain and precarity into which they have been forced and that have been indelibly inscribed in their bodies (Montaldo, "La invasión").

Critics have unanimously highlighted the ability of Arrieta and his nonprofessional actors to adapt to the society of the spectacle by playing themselves; Gonzalo Aguilar, for example, contrasts the naiveté of marginalized subjects in the past-when a gaucho would shave and change clothes after hearing that he would be filmed, thus losing his chance at being in the movieto the skills, seen among Arrieta and his company, at showcasing the "authentic" poverty that audiences want to see (New Argentine Film 240; see also Pauls; Montaldo, "La invasión"; Giorgi 76-77). What I would emphasize, however, is that the pragmatic exhibition of poverty documented in Estrellas foregrounds the power differential that defines the desire for narratives that depict the encounter with the "other." The film, in that sense, highlights class tensions not only by disrupting the quest for an exotic and ultimately harmless authenticity but also by interrogating the very possibility of acting. In particular, the film's unlikely actors-who place the oxymoron of the poor star at the film's center of gravity - enable it to pose such implicit but far-reaching questions as Who has a right to act?, What roles are available for the people of the slum?, and What are the conditions for acting, for having the necessary agency to transform oneself or transform the world?

In Latin America, these questions are related to a long history of cultural encounters between relatively well-off artists and subaltern sectors of society; in terms of literature, for example, we could mention the nineteenth-century gauchesca poetry (where the gaucho dialect is folded into the intellectual's attempt to speak for him) or, in terms of theater and performance, the teatro del oprimido ("theater of the oppressed") developed in the 1960s, which linked workers, marginalized people, and artists in a collective, interactive project. In the medium of film in particular, and also in the 1960s, retrospectively baptized "Third Cinema movements" throughout the region (including the $\mathrm{Ar}$ gentine Grupo Cine Liberación) argued for the specificity of a Third World, Latin American reality through the creation of films in which collectivist 
values played a central role; in the 1970s and 1980s, movements of indigenous media provided marginalized groups with cameras in order for them to document their oppression and reflect upon it. All of these movements have problematized the monopoly of artistic expression on the part of the upper classes even as, in some ways, they have also reaffirmed it.

In keeping with this long line of interrogation that characterizes Latin American cultural production, Estrellas and El nexo humorously explore the ways in which their characters can be thought of as actors-and what is more, as stars. Both mass culture and high culture, Arrieta insists, should be open to everybody: among the material that it incorporated from TV archives, Estrellas includes a news report on the theater group in Slum 21-24 with the catchy headline, "Shakespeare in the Slum." Following the display of the fictional website, Estrellas also includes an intertitle that summarizes this preoccupation: "When will a construction worker be a protagonist of something?" In the long scene that follows, the last in the film, we see this dream come true-Arrieta and his wife riding a car in a peaceful rural road very far from the slum, silent and content, accompanied by a catchy, kitschy tune that recalls generic happy endings. They do not look like Hollywood stars, though; rather than a convertible, they are riding in an old Ford Falcon and drinking mate, the typical Argentine infusion. The danger of reifying the identity of the subaltern is thus eclipsed by this ironic play with stardom.

The irony transmitted by this last scene amplifies Arrieta's own, for while he demands that slum dwellers have access to the same roles that professional actors usually play, he also seems to know that what makes their celebrity possible is precisely its unexpectedness - the fact that such persons are usually excluded from those roles. And by showing the impossibility of fulfilling this utopian demand in any way that does not look "poor" and therefore ironic (as in the scene with the Ford Falcon), both El nexo and Estrellas foreground the constrictions and the precarity of cultural agents in the slum. The reappropriation of poverty, in other words, allows them to become agents of their own dispossession. In a world in which poverty is structural, they seem to say, the poor should have at least the right to own the image of their own deprivation, which they can either sell as authentic, mock as stereotypical, or exhibit as a telling example of inequality.

If by exceeding usual norms of verisimilitude, science fiction movies like El nexo allow us to imagine a reconfiguration of the social body in which marginalized sectors can be at the center of history, Estrellas helps us to do the same by exploring our assumptions of what actors or stars are. These films propose a new type of gaze that, instead of focusing on the ways in which privilege is patrolled and transmitted from generation to generation, discovers hitherto unseen powers of the poor: in the case of El nexo, earth-saving powers such as killing the aliens with rotten water, a feat inconceivable in other parts 
of the city where physical and symbolic sewage systems make disavowal much easier; in the case of Estrellas, the power of the poor to reveal the workings of social inequality by showing the poverty of a society that expects slum-dwellers to stick to their usual roles, to stay in their place. What Estrellas shows, in fact, is that being in a place-being in the slum-is something very different from having to stay somewhere; it shows, in other words, that what we refer to as poverty or destitution is not characterized by passivity but by the very active paradigm of "making do."

In this sense, the film includes a three-minute monologue in which Arrieta tells about the visit that Alan Parker paid to Slum 21-24 when he was looking for locations for his film Evita (1996). During that meeting, Parker observed that there were too many exposed television antennas to shoot his period piece there, to which Arrieta replied: "If there's money, as you say, we'll rent a vacant bit of land, and in one hour I'll make you twenty sheds, I'll put people from the slum inside them, and I'll even throw in a blow job." The next scene of the film is aimed at showcasing Arrieta's skills as an urban developer: with a handful of other workers, he builds a typical corrugated-tin shed in what the counter included in the shot reveals to be a total of two minutes and twenty seconds; exactly one minute later, the shed has been furnished and we can see him sitting inside with his family, drinking mate. Arrieta and his fellow bricoleurs (including, of course, the directors) thus present us with a metonymy of the socially unequal urbanization that forces hundreds of millions of people around the world to construct, as quickly as possible and with whatever materials are available for them, homes for themselves outside of legally sanctioned spaces.

Inasmuch as it shows how people can construct something out of seemingly nothing, this scene epitomizes the film's paradigm of "making do." The explicit reason for constructing the shed is Julio Arrieta's desire to show his skills at creating "real" locations for TV or film projects and in that sense at selling poverty. Critics, in fact, have convincingly compared this scene with a famous 1968 performance by the Argentine avant-garde artist Oscar Bony called "La familia obrera" ("The Working Class Family"), which exhibited a father, his wife and his son, as well as a sign explaining that the artist was paying this worker a salary twice as high as his normal one for being on display (Amado 98; Cortés-Rocca, "La villa"). And it would be unprofessional of me to overlook the problematic tension between the slum dwellers who sell poverty and the middle-class artists who visit them, not to mention the scholars who earn a living by writing about all of this; this long shot, in fact, could be easily read in those terms, inasmuch as the shed is being constructed for the camera, which voyeuristically contemplates the performance. Yet while the filmmakers certainly linger on the distance that separates them from poverty, we can also read this distance as humbling, respectful. After all, what the camera witnesses is the construction not just of a shed, but of a home, of the 
new life of a family, thus revealing the uncanny closeness of precarity and security, of destitution and ownership, of shame and pride. The "now you see it, now you don't" reality of the slum, where a shed can emerge as quickly as it later disappears when the bulldozers of real-estate developers or the state arrive, is reminiscent of the wheel of fortune: reminiscent, that is, of the idea that no one is absolutely sheltered, that any "self" can eventually become an "other"-an idea that El nexo articulates in terms of an alien invasion, and Estrellas in terms of an "invasion" of poor stars. Moreover, if throughout history personhood has been often inseparable from the condition of ownership, of owning property, this long shot shows us that the members of this family are not only performing for the camera but also becoming propertied persons; even if we may contest their ownership of that piece of land, in just a few seconds of living in the shed they are able to look back at us from the position of sovereignty of what already seems to be their home. ${ }^{8}$

\section{THE REAPPROPRIATION OF POVERTY IN CONTEMPORARY BUENOS AIRES}

The years immediately following the 2001-02 economic crash in Argentina were characterized by an unprecedented attention to urban poverty on the part of mass media, literature, and the arts. As Alan Pauls has pointed out in his analysis of Estrellas, this was a decade that began with the ubiquitous presence of marginal people in TV talk shows-from drug dealers to the informal recyclers known as cartoneros ("cardboard pickers") — and a number of very successful TV mini-series devoted to the representation of poverty and marginality, such as the ground-breaking Okupas (Bruno Stagnaro, 2000), which focused on squatter-occupied housing in Buenos Aires, and Tumberos (Adrián Caetano, 2002), which portrayed life in prisons. Recent films such as La 21 Barracas (Víctor Ramos, 2010) seem to suggest that interest in these issues persists. ${ }^{9}$

This attention to urban poverty was probably due not only to the fact that $57.5 \%$ of the country's population was living under the poverty line in 2002 (Bertranou and Bonari 371) but also to a new political climate. Inaugurated the following year, the era of Kirchnerismo (Néstor Kirchner was president until 2007, and was succeeded by his wife Cristina Fernández, who is currently on her second term) can be described as a leftist articulation of Peronism that, among other things, has aimed at expanding the welfare state and fostering a type of political discourse that, openly contesting the tenets of neoliberalism, gives precedence to the public over the private and to the interests of "el pueblo" ("the masses" or "the people") over those of the economic elite. In this political context, cultural production has been increasingly defined by an interest not in representing poverty but in reappropriating it as a social locus that can be proudly embraced, inasmuch as the "poor" are framed as legitimate historical actors. 
Taking into account the way in which a populist political discourse has sharpened class tensions during the last decade (and, in particular, after 2008) is therefore a necessary step in any understanding of the signifier "poverty" in contemporary Argentina. A clear example of these class tensions was the notorious verbal exchange of 2008, in which the radio host Fernando Peña called the son of a pro-government activist "negro de mierda" (the closest translation would be “nigger”). This activist, Luis D'Elia, responded in the following way from his home in the squatter settlement that he has helped to construct:

I hate the fucking oligarchy, I hate white people.... I have a visceral hatred of you all, the north of the city.... Hear it from my lips. You think that the people who follow me are just trash, human scum ... black, ugly, horrible. ... I hate you, Peña, I hate your money, I hate your house, your cars, your history, I hate the people like you, who defend an unfair and unequal country. ("La explosiva carrera") ${ }^{10}$

D'Elia signed off this declaration by naming the exact location from where he was speaking- "Laferrere, Slum Tambo"-as a kind of authorizing gesture. Far from being a fringe episode, this exchange, which also included an open letter by Peña to the president of Argentina, was reproduced by the main news organizations and generated a heated debate about class divisions and racism (Adamovsky 356-57). This debate certainly contributed to create the conditions of possibility for the recent relocation of the national Secretariat of Culture, which was moved from the high-class neighborhood of Recoleta to Slum 21-24 ("Cristina Kirchner").

Often more removed from immediate verbal and physical confrontation than activists like D'Elia, other important Argentine cultural agents of the first decade of the twenty-first century have also defined their own place in society by creating a symbolic alliance with poverty. As Graciela Montaldo has observed, this was certainly the case of the directors of Estrellas, but also of the now emblematic Eloísa Cartonera, a publishing house organized as a cooperative in 2003 which produces hand-made books with covers made out of cardboard ("cartón") and has sparked a number of similar projects across the hemisphere, from Bolivia to Madison, Wisconsin ("El mundo" 8; see also Bilbija and Carbajal). Since the presence of thousands of cartoneros in the streets of Buenos Aires was one of the more clear signs of the economic crisis faced by the country at the beginning of the decade, buying the cardboard from them and creating unapologetically precarious covers was a clear comment on the alliance between literature and poverty. (The same could be said about the fact that Eloísa began by selling not just books but also vegetables: the ubiquitous produce stands, often run by lower-class immigrants from neighboring countries, are some of the humblest business ventures in Argentina). What the young artists in charge of Eloísa wanted to emphasize was precisely the encounter 
between trash-marginalized people who were increasingly the norm on the streets of Buenos Aires-and the writers in their catalogue, which included more than a few illustrious names like Ricardo Piglia and César Aira.

In addition to this reflection on the relationship between literature and precarity through the figure of cardboard, writers have also developed a number of fictions that explore the foundational role of poverty in the realm of politics, community organization, and social identity. In fact, as Cortés-Rocca has argued, the centrality of the slum in novels such as La boliviana (Ricardo Strafacce, 2008) and La virgen cabeza (Gabriela Cabezón Cámara, 2009) opens up the possibility of conceiving of Latin American identity in terms of a shared and constitutive dispossession: "a community conformed, like the populist subject, by a 'not having"” ("Variaciones" 41). ${ }^{11}$ Both novels, I would emphasize, are marked by a satirical reappropriation of poverty: in La boliviana, the contaminated stream that runs next to the slum has given birth to radioactive toads that are immune to everything and transmit that immunity to whoever eats them, prompting a drug dealer, who also happens to work for one of the biggest pharmaceutical corporations in the world, to invade the place with an army of researchers; in La virgen cabez $a,{ }^{12}$ the wealth of poverty manifests itself through a slum fish farm of carp, a bottom-feeding species depicted in the novel as capable of eating absolutely anything. Writers, in this sense, approach the realm of poverty as a source not so much of themes or content as cunning, humor and survival strategies (Cortés-Rocca, "La villa").

The ability to work with junk, waste, or refuse has been long considered indispensable by Argentine artists like Mauricio Kartún, an extremely influential playwright and director who has defined imagination as a ragpicker who "recycles waste, scraps, worn-out images" (qtd. in Dubatti 117). Among the countless theater plays that have been based on this logic, I would like to mention a very recent one, Alberto Ajaka's El director, la obra, los actores y el amor (The Director, the Work, the Actors, and Love, 2013), which takes it to an eschatological extreme. Like the scene in Estrellas in which a shed is constructed out of the blue, this play emphasizes how much can be created with almost nothing by showing the sudden construction of a shaky wooden outhouse: in a ludicrous manifestation of the paradox of the wealth of poverty, it becomes a time machine that allows the theater company to receive the visit of Leónidas Barletta, a mythic (and populist) theater director of mid-twentieth-century Argentina. The time machine serves a basic purpose: to help the company figure out what they are doing on stage. As Ajaka himself explains to the public from the left side of the theater at the beginning of the performance, the show, which is part of a city-government-sponsored theater series, is actually a rehearsal for a piece that the company hopes to eventually perform with the ten thousand pesos (about 1600 dollars at the official and standard exchange rate-there were several other rates in Argentina-during the week I saw the 
play) that they received to participate in the series (El director). El director is thus a perfect example of a form of contemporary theater that the Argentine critic Jorge Dubatti describes in terms of its capacity to produce sense out of the senseless, obtain richness from poverty, and ultimately, as the director $\mathrm{Ri}-$ cardo Bartís has argued, to transform precarity into an ideological and aesthetic weapon (qtd. in Dubatti 118).

The reappropriation of poverty is the thread that weaves together El nexo, Estrellas and the other works cited in this last section of my essay. Whether by using the rotten water of Buenos Aires's biggest slum as a lethal weapon, by proposing that slum dwellers earn wages for "bearing a face" that fits the stereotypical profile of the poor demanded by film and mass-media, or by transforming an outhouse into a time machine, artists bring into sharp relief the fact that the conditions for agency in Argentina are usually marked by a perceived lack that simultaneously functions as a limit and a starting point; they are marked, in other words, by a critical acceptance of one's own poverty, which prompts and authorizes subsequent efforts to "make do." The creative paradigm fostered by this reappropriation of poverty might provide a fruitful point of departure for developing comparative analytical models of the cultures of the Global South.

\section{Notes}

1. "[E]s la primera vez que el Estado llega con esta presencia tan activa a un lugar como la villa Barracas, la más importante de Buenos Aires" (qtd. "Cristina Kirchner”), translated by the author.

2. The bricoleur, Claude Lévi-Strauss famously wrote, is adept at performing a large number of diverse tasks, but, unlike the engineer, he does not subordinate each of them to the availability of raw materials and tools conceived and procured for the purpose of the project. His universe of instruments is closed, and the rules of his game are always to make do with "whatever is at hand," that is to say with a set of tools and materials which is always finite and is also heterogeneous, because what it contains bears no relation to the current project, or indeed to any particular project, but is the contingent result of all the occasions there have been to renew or enrich the stock or to maintain it with the remains of previous constructions or destructions (17).

3. It might be worth pointing out that such expertise could be at the base not only of artistic creation but of modern engineering and scientific development, as exemplified by the recent launching of a spacecraft to Mars from India. What made possible this $\$ 75$ million mission (as the New York Times pointed out, it required considerably less money than the blockbuster film Gravity) was precisely this know-how, known in Hindi as "Jugaad" (Rai B3; Jauregui 77).

4. For a list of films, TV productions and other cultural projects in which he has participated, see Arrieta.

5. On the importance of cheapness for the definition of B-movies and other "cheesy" forms of film, see Newitz. On Argentine B-Movies, see Aguilar, New Argentine Film 188.

6. In recent Argentine history, another episode related to the former British Empire shows the appeal of imagining that victory might result precisely from unexpected, unconventional, and even atavistic 
weapons such as those at the base of El nexo. During the 1982 Falklands war some Argentines responded to the danger supposedly posed by the Gurkhas, soldiers of Nepalese origin fighting for the UK and known for their curved-blade kukris, by praising the gaucho's dexterity in the use of the knife (Oliva 331). It should be noted that the figure of the gaucho is central to Argentine constructions of national identity, in particular after the nineteenth-century, when the expansion of the state and "civilization" exterminated his power. The online Encyclopedia Britannica defines him as follows: "the nomadic and colourful horseman and cowhand of the Argentine and Uruguayan Pampas (grasslands), who flourished from the mid-eighteenth to the mid-nineteenth century and has remained a folk hero similar to the cowboy in western North America."

7. I use the expression "constitutive outside" in reference to Judith Butler's contention that "one achieves and maintains 'social existence' only by the production and maintenance of those socially dead" (Psychic Life 27).

8. None of this should lead, of course, to a romanticization of slums, which are spaces that tend to reproduce exploitation and are internally divided by a wide range of landlords, renters, and homeless (Davis 82).

9. On the representation of slums in Argentine film, cf. Aguilar, "La representación."

10. "Odio a la puta oligarquía, odio a los blancos ... Tengo un odio visceral contra ustedes, el norte de la ciudad ... sépanlo de mi boca. Ustedes piensan que la gente que me sigue a mí es pura basura, escoria humana ... negra, fea, horrible ... Te odio Peña, odio tu plata, odio tu casa, tus coches, tu historia, odio a la gente como vos que defiende un país injusto e inequitativo" ("La explosiva carrera"), translated by the author.

11. The populist subject, Cortés-Rocca clarifies, has been defined by Ernesto Laclau as a historical agent clearly opposed to an enemy on the basis of a chain of unfulfilled demands. See also Laclau 75.

12. The title seems to refer both to the author's last name and to an imagined Catholic Virgin of the "cabeza" or "cabecita negra"-a (reappropriated) racist denomination that literally means "little black head."

\section{Works Cited}

Adamovsky, Ezequiel. "El color de la nación argentina. Conflictos y negociaciones por la definición de un ethnos nacional, de la crisis al Bicentenario.” Jahrbuch für Geschichte Lateinamerikas Anuario de Historia de América Latina 49 (2012): 343-64. Print.

Aguilar, Gonzalo. New Argentine Film: Other Worlds. Trans. Sarah Ann Wells. London: PalgraveMacmillan, 2011. New Concepts in Latino American Cultures. Print.

. "La representación de las villas en el cine." Informe Escaleno, 18 Nov. 2013. Informe Escaleno. com.ar. Web. 15 Jan. 2014.

Amado, Ana. "Arte participativo. El trabajo como (auto) representación.” Significação 34 (2010): 87-102. Print.

Arrieta, Julio. Arte Villa Producción. Blogspot.com. Web. 12 Mar. 2015.

Bayat, Asef. "Un-civil Society: The Politics of the 'Informal People.” Third World Quarterly 18.1 (1997): 53-72. Print.

Bertranou, Fabio M., and Damián Bonari, eds. Protección social en Argentina. Financiamiento, cobertura y desempeño 1990-2003. Santiago: Oficina Internacional del Trabajo, 2005. Print.

Bilbija, Ksenija, and Paloma Celis Carbajal, eds. Akademia Cartonera: A Primer of Latin American Cartonera Publishers. Madison: Parallel, 2009. University of Wisconsin-Madison Libraries. Print.

Butler, Judith. Precarious Life: The Powers of Mourning and Violence. New York: Verso, 2006. Print. .The Psychic Life of Power: Theories in Subjection. Stanford: Stanford UP, 1997. Print.

Cámara Cabezón, Gabriela. La virgen cabeza. Buenos Aires: Eterna Cadencia Editora, 2009. Print. 
Certeau, Michel de. The Practice of Everyday Life. Berkeley: U of California P, 1988. Print.

Cortés-Rocca, Paola. "Variaciones villeras: nuevas demarcaciones políticas." Revista Hispánica Moderna 64.1 (2011): 39-48. Print.

. "La villa: política contemporánea y estética." Revista de Estudios Hispánicos 48.1 (2014): $183-$ 99. Project MUSE. Web. 13 Mar. 2015.

"Cristina Kirchner anunció el traslado de la Secretaría de Cultura a la Villa 21." La Nación, 9 Sept. 2013. LaNacion.com.ar. Web. 15 Jan. 2014.

Davis, Mike. Planet of Slums. New York: Verso, 2007. Print.

El director, la obra, los actores y el amor. By Alberto Ajaka. Dir. Alberto Ajaka. Centro Cultural Ricardo Rojas, Buenos Aires. 26 July 2013. Performance.

Dubatti, Jorge. "Teatro argentino y destotalización: El canon de la multiplicidad." Foro Hispánico: Revista Hispánica de Flandes y Holanda 24 (2003): 111-24. Print.

Estrellas. Dir. Federico León and Marcos Martínez. Perf. Julio Arrieta. Crudo, 2007. Film.

“La explosiva carrera pública de D’Elia en la era K." La Nación, n/d. LaNacion.com.ar. Web. 15 Jan. 2014.

García Villegas, Mauricio, ed. Normas de papel. La cultura del incumplimiento de reglas. Bogotá: Siglo del Hombre Editores, 2010. Print.

"gaucho." Encyclopaedia Britannica Online. Encylopaedia Britannica, 2013. Web. 12 Mar. 2015.

Giorgi, Gabriel. "Improper Selves: Cultures of Precarity." Social Text 31.2 (2013): 69-81. Print.

Graham-Yooll, Andrew. "Descubramos que podemos pensar, por el bien de los villeros." Página/12, 3 Feb. 2003. Pagina12.com.ar. Web. 12 Mar. 2015.

Halfon, Mercedes. “Avanti Morochos." Página/12, 13 Dec. 2007. Pagina12.com.ar. Web. 12 Mar. 2015.

Huggan, Graham. The Postcolonial Exotic: Marketing the Margins. London: Routledge, 2001. Print.

Jauregui, Beatrice. "Provisional Agency in India: Jugaad and Legitimation of Corruption." American Ethnologist 41.1 (2014): 76-91. Print.

Laclau, Ernesto. On Populist Reason. London: Verso, 2005. Print.

Lévi-Strauss, Claude. The Savage Mind. Chicago: U of Chicago P, 1996. Print.

Ludmer, Josefina. La sartén por el mango. Río Piedras: Huracán, 1984. Print.

Monsiváis, Carlos. Aires de familia. Cultura y sociedad en América Latina. Barcelona: Anagrama, 2000. Print.

Montaldo, Graciela. "La invasión de la política." Performance $\neq V i d a$. Spec. issue of E-Misférica 8.1 (2011): n. pag. HemisphericInstitute.org. Web. 15 January 2014.

. "El mundo de la cultura." Revista Hispánica Moderna 64.1 (2011): 1-9. Print.

Newitz, Annalee. "What Makes Things Cheesy? Satire, Multinationalism, and B-Movies." Social Text 18.2 (2000): 59-82. Print.

El nexo. Dir. Sebastián Antico. Perf. Julio Arrieta, Ysmael Elizaur, and Karina Hidalgo. Universidad del Cine, 2005. Film.

Oliva, Enrique [François Lepot]. Malvinas desde Londres. Buenos Aires: Editorial Ciudad Argentina, 2002. Print.

Pauls, Alan. "Los actores sociales." Página/12, 9 Dec. 2007. Pagina12.com.ar. Web. 15 Jan. 2014.

Rai, Saritha. "From India, Proof That a Trip to Mars Doesn't Have to Break the Bank." New York Times, 18 Feb. 2014: B3. Print.

Ruétalo, Victoria. "From Villa to Village: Situating Argentina's Theatrical Coordinates on the Global Map." Studies in Latin American Popular Culture 21 (2002): 175-87. Print.

Scott, James C. Weapons of the Weak: Everyday Forms of Resistance. New Haven: Yale UP, 1985. Print. Strafacce, Ricardo. La Boliviana. Buenos Aires: Mansalva, 2008. Print.

Straub, Julia. "Introduction: The Paradoxes of Authenticity." Paradoxes of Authenticity: Studies on a Critical Concept. Ed. Julia Straub. Bielefeld: Transcript-Verlag, 2012. 9-32. Print.

Wild-Wood, Emma. "Se Débrouiller' or the Art of Serendipity in Historical Research." History in Africa 34 (2007): 367-81. Print. 